https://doi.org/10.19195/0137-1150.173.44

Data przesłania artykułu: 20.09.2019

Data akceptacji artykułu: 15.01.2020

MARTA CHASZCZEWICZ-RYDEL

Uniwersytet Wrocławski, Polska

\title{
Pamięć w przestrzeni publicznej Belgradu i jej literackie transformacje Svetlana Velmar-Janković
}

Jądrem każdego miasta jest przestrzeń publiczna, czyli sfera najintensywniejszych ludzkich przepływów, w której zlokalizowane są elementy spuścizny materialnej o znacznych walorach kulturowych i symbolicznych ${ }^{2}$. Jej ważnymi atrybutami są wpływanie na wizerunek miasta oraz podleganie kontroli ze strony władzy. Można ją także postrzegać jako system komunikatów zredagowanych przez lokalnych mieszkańców, jako ciąg opowieści modelujących status ontologiczny i aksjologiczny minionych zdarzeń, jak również jako wyraz „wartości uznawanych przez daną społeczność"3.

Zebrane w niniejszym tomie rozważania koncentrują się wokół zjawisk związanych ze zwrotem memoratywnym, ,pamięcią zbiorową”, , antropologią pamięci” czy „pamięcią kulturową"4, moim celem jest natomiast wskazanie na związek pamięci z miejscem, co oznacza cofnięcie się do obszaru refleksji związanej ze zwro-

1 Hymny orfickie, przeł. i oprac. E. Żybert, Wrocław 2012, s. 103, cyt. za: Mnemosyne. Pamięć jako źródło dzieła sztuki, red. M. Cieśla-Korytkowska, J. Czernik, Kraków 2016, s. 11.

2 Por. M. Rogowska, Przestrzeń publiczna w mieście — zagadnienia wybrane, „Studia KPZK” 2016, nr 170, s. 159.

3 Ibidem, s. 160.

${ }^{4}$ Por. B. Korzeniowski, Transformacja pamięci: przewartościowania w pamięci przeszłości a wybrane aspekty funkcjonowania dyskursu publicznego w Polsce po 1989 roku, Poznań 2010. 
tem przestrzennym notowanym w naukach humanistycznych od lat osiemdziesiątych. Emancypacja tej problematyki łączy się ze stanowiskiem konstruktywistycznym; wynika ze spostrzeżenia, że ,przestrzeń nie jest neutralnym, jednakowym dla wszystkich [...] przezroczystym słojem, w którym przebiega ludzkie życie, lecz jest na bieżąco tworzona, kształtowana i podtrzymywana przez ludzi wchodzących ze sobą w relacje"s.

Tematyka przestrzeni publicznej, miejsca i pamięci łączy się w literaturze serbskiej zwłaszcza ze stołecznym Belgradem, któremu towarzyszy, dające się zauważyć, szczególne bogactwo różnorodnych publikacji: autobiografii mieszkańców, przewodników po belgradzkiej rzeczywistości społeczno-kulturowej (Aleksandar Dereko, Bogdan Tirnanić, Nenad Novak Stefanović), powieści i opowiadań rozgrywających się w stolicy (Milutin Uskoković, Borislav Pekić, Milorad Pavić, David Albahari, Goran Petrović i inni), historii Belgradu pisanych przez samych pisarzy (Milorad Pavić), literackich portretów miasta (Momo Kapor). Wątki belgradzkie najbardziej reprezentowane są w twórczości Svetlany Velmar-Janković 6 , pisarki i dziennikarki balansującej na pograniczu literatury wysoko artystycznej i popularnej. Stolicy Serbii dedykowała ona wiele utworów, lecz tu chciałabym poświęcić uwagę tekstowi Dorćol, który został wydany w 1981 roku i nagrodzony wyróżnieniem imienia Iwa Andricia. Książka jest literackim przewodnikiem po mieście, a formalnie zbiorem opowiadań zatytułowanych nazwami czternastu ulic najstarszej po Kalemegdanie części Belgradu. Łączy je przede wszystkim czasoprzestrzeń dziewiętnastowiecznego Dorciolu, albowiem patroni wybranych przez pisarkę ulic pochodzą z okresu odnowy serbskiego państwa ${ }^{7}$, spaja je także nadrzędna myśl o metropolialności Belgradu jako ośrodka władzy politycznej, o kumulowaniu się w jego murach kapitału ekonomicznego, infrastrukturalnego, kulturowego, a wreszcie społecznego, ponieważ od wieku XIX tworzył skupisko jednostek kreatywnych, skupisko talentu ${ }^{8}$.

${ }^{5}$ M. Löw, Socjologia przestrzeni, przeł. I. Drozdowska-Broering, red. i wprowadz. M. Bucholc, Warszawa 2018, s. 12.

6 Svetlana Velmar-Janković (1933-2014) urodziła się i wychowała w Belgradzie. Współtworzyła czasopismo „Književnost” oraz wydawnictwo Prosveta. Od 2006 roku była członkiem SANU. Jest autorką powieści: Ožiljak (1956), Lagum (1990), Bezdno (1995), Nigdina (2000), Vostanije (2004), esejów: Savremenici (1967), Ukletnici (1993), Izabranici (2005), Srodnici (2013), wspomnień: Prozraci (2003), opowiadań: Dorćol (1981), Vračar (1994), Glasovi (1997), Knjiga za Marka (1998), Očarane naočare: priče o Beogradu (2006), Sedam mojih drugova (2007), modlitwy: Svetilnik (1998), dramatu: Knez Mihailo (1994) oraz monografii: Kapija Balkana: brzi vodič kroz prošlost Beograda (2011). Za swą twórczość została wielokrotnie nagrodzona. Otrzymała między innymi nagrody: Isidora Sekulić, im. Iwa Andricia za zbiór Dorćol, NIN za Bezdno (1995) jako najlepszą powieść roku.

7 Z czasu pierwszego i drugiego powstania serbskiego oraz pierwszej fazy panowania dynastii Obrenoviciów.

8 Por. Z. Rykiel, Metropolie jako źródło kapitalu, [w:] Przestrzeń społeczna miast i metropolii w badaniach socjologicznych, red. Z. Rykiel, Rzeszów 2014, s. 15. 
Velmar-Janković odwołuje się do fragmentów historii politycznej Serbii, leżących u podstaw serbskiej tożsamości narodowej, do jej założycielskich mitów. Wspomina wielokrotnie postaci takie, jak Karađorđe, Miloš Obrenović, Dositej Obradović, Vuk Stafanović Karadžić, a więc osoby mocno zapisane w pamięci zbiorowej i uwiecznione w rozlokowanych po mieście monumentach. Jej strategia obejmuje także przywracanie pamięci o związanych z Dorciolem mniej znanych ludziach. Z opowiadań wyłaniają się sylwetki Gospodar Jovana, Gospodar Jevrema, Mihaila Anastasijevicia, Uzun Mirka, Zmaja od Noćaja, Rigi de Fere. Pisarka nadaje im konkretne osobowości, nawiązuje do biogramów i zasług dla rozwoju miasta, odtwarza sieć relacji społecznych, w których funkcjonowali. Jej wywody można sytuować w sferze zdefiniowanej przez Jana Assmanna pamięci kulturowej, o której mówimy, gdy wygasły już zarówno relacje świadków jak i międzypokoleniowy dialog, a upamiętnianie nabiera charakteru zewnętrznego, materialnego.

O ile bowiem pamięć komunikacyjna jest relatywnie krótkotrwała i ulotna, to pamięć kulturową charakteryzuje stałość [...]. Jest ona fundamentem zbiorowej tożsamości i kolektywnego wyobrażenia o przeszłości. [...] koncentruje się na takich punktach z przeszłości, które z czasem krystalizują się jako „figury symboliczne" 9 .

Velmar-Janković ożywia funkcjonujące niegdyś w lokalnej świadomości opowieści dotyczące poszczególnych punktów topograficznych, uruchamia ich znakowy potencjał, tym samym dowodząc, że miasto to przestrzeń pamięci, a rozlokowane w niej miejsca mają charakter pamięciowych mediów.

\section{Dorciol albo Stary Belgrad}

Zainteresowanie przestrzenią u Velmar-Janković przybiera formę intelektualnej podróży. W pewnej mierze afirmuje ona miejsce, w którym żyje, ale w jej narracji stan harmonii z otoczeniem ${ }^{10}$ wyrażalny jest, dopiero gdy następuje otwarcie współczesności na przeszłość. Jest to kierunek zupełnie uzasadniony, ponieważ interesujący ją obszar, tytułowy Dorciol ${ }^{11}$, leży w dzielnicy staromiejskiej, w której do XIX wieku pełnił funkcję centrum orientalnej kasby. Dziś znajduje się on w sąsiedztwie najbardziej reprezentacyjnej części Belgradu, lecz zajmuje miejsce poboczne, mniej wyeksponowane i wyraźnie zdane na wpływy czasu. Choć przez

9 M. Saryusz-Wolska, Pamięć zbiorowa i kulturowa. Wspótczesna perspektywa niemiecka, red. M. Saryusz-Wolska, Kraków 2009, s. 31-32.

10 Por. R. Woźniak, Miejsce do mieszkania, miejsce do kochania..., Wystawa Katedry Sztuki i Kultury Plastycznej Uniwersytetu Zielonogórskiego, przeł. A. Rozwadowska, W. Prankiewicz, Zielona Góra 2007, s. 4.

11 Od początku XX wieku nazwą „Dorćol” określa się cały obszar od Kalemegdanu do ulicy Francuskiej. Niektóre źródła podają, że rozciąga się on wzdłuż osi: od placu Studenckiego do Kalemegdanu i od Skadarliji do Dunaju - Д. Замуровић, Мој Београд, Београд 2013. Niegdyś tak nazywała się część Belgradu poniżej ulicy Cara Dušana, gdzie skupiała się przede wszystkim ludność pochodzenia tureckiego, greckiego i żydowskiego. 
setki lat tworzył główną tkankę Starego Belgradu, ze struktur dawnej zabudowy ocalały jedynie pojedyncze obiekty. Zachował się też układ przestrzenny Starej čaršii, która przebiegała wzdłuż dzisiejszej ulicy Króla Piotra.

„Dort-jol”, jak za Milanem Kosticiem tłumaczy Velmar-Janković, oznacza w języku tureckim skrzyżowanie czterech dróg, gdyż nazwa pochodzi od przecięcia ulic Cara Dušana i Kralja Petra, które kiedyś wiodły do Stambułu, Wiednia i Dubrownika. Teren ten rozwijał się bujnie w XVII i XVIII wieku, tworząc centrum handlowe miasta. Swym kształtem przypominał wówczas typowe miasto Wschodu: znajdowały się tutaj karawanseraj i bezistan Mehmeda Pašy Sokolovicia, hany, kafany i liczne dżamie ${ }^{12}$. Próby barokizacji i urbanizacji w stylu zachodnim podjęli Austriacy po zdobyciu Belgradu w pierwszej połowie XVIII wieku. W roku 1740 Dorciol przechodzi ponownie w ręce Turków i znów uzyskuje orientalny charakter, by na przełomie XVIII i XIX wieku stać się przestrzenią bardzo zaniedbaną i zrujnowaną, która dopiero pod panowaniem serbskim, za sprawą rozwoju handlu, znów nabierze życia.

W historii rozwoju Dorciolu, i całej Serbii, przełomowy okazał się wiek XIX, bogaty w zdarzenia, które zadecydowały o jego współczesnej przynależności politycznej. Pod panowaniem księcia Miloša Obrenovicia Belgrad zmienia się w serbskie miasto ${ }^{13}$. „Pojawiają się wtedy początki serbskiej administracji i władz sądowniczych oraz podstawy życia gospodarczego i kulturalnego, które będzie się rozwijać wraz z budowaniem nowego państwowego porządku w całym XIX wieku"14.

Miasto otaczały szaniec i palisada, do wnętrza można się było dostać czterema bramami (Sava-kapija, Varoš-kapija, Stambol-kapija, Vidin-kapija), gdzie usytuowano także siedziby serbskich urzędów. Teren dzisiejszego dorciolskiego Zereka (od placu Studenckiego na północ) składał się z wąskich krętych uliczek, przy których w niewysokich domach, otoczonych ogrodami, zamieszkiwała ludność turecka; z czasem jej domostwa przechodziły w ręce odkupujących je Serbów ${ }^{15}$. Był tu także turecki cmentarz.

Velmar-Janković nie kreśli całościowej historii Dorciolu. Pomija okres rzymski, nie wspomina o średniowiecznym, koncentruje się na wybranych faktach z historii rozwoju dziewiętnastowiecznego mieszczaństwa. Tworzy raczej „przestrzeń wyimaginowanych ojczystych stron" ${ }^{\prime 16}$, na którą składają się określenia realne, terytorialne, fizyczne oraz symboliczne.

12 Por. ibidem, s. 19.

13 Za czasów księcia Miloša miasto jest dwudzielne — składa się z twierdzy, która pozostawała w rękach osmańskich, oraz multikulturowej aglomeracji.

14 Историјски атлас Београда, oprac. D. Lakićević, Beograd 2016, s. 109.

15 Symboliczne przekazanie Serbom kluczy do miasta nastąpiło dopiero 6 kwietnia 1867 roku za panowania księcia Mihaila, który przejął je z rąk komendanta twierdzy, Ašir Pašy. Choć do roku 1878 formalnie Kragujevac zostanie stolicą autonomicznego Księstwa Serbskiego, Belgrad w coraz większym stopniu będzie przejmował funkcję centrum życia społecznego, ekonomicznego i kulturalnego Serbii - Н. Бура, Илустрована хронологија Београда, Нови Сад 2004.

16 D. Bachmann-Medick, Cultural turns. Nowe kierunki w naukach o kulturze, przeł. K. Krzemieniowa, Warszawa 2012, s. 356. 


\section{Nośniki pamięci}

Na podstawie zbioru opowiadań Dorćol możemy zbudować imaginacyjną mapę, która jest osadzona na wyłuskanych $\mathrm{z}$ realnej przestrzeni punkach topograficznych, otwartych na pamięć. Należy do nich kamienica bogatego rymarza Eliasa Fleischmanna, Muzeum Vuka i Dositeja, to jest budynek, w którym mieściła się Wielka Szkoła Ivana Jugovicia, Kapetan Mišino zdanje, dom Miloja Božića, czyli dzisiejsze Muzeum Teatru, oraz Bajrakli džamija. Obiekty te są traktowane jako medium przenoszące stykający się z nimi, refleksyjny podmiot ku czasom minionym.

Velmar-Janković, prowadząc dialog z historią, wykazuje się swoistym, ,słuchem pamięci”, czyli „umiejętnością dostrzegania [jej - M. Ch. R.] wielu różnych nośników" ${ }^{17}$. Wśród stosowanych przez nią środków poetyckich, które służą powrotom do przeszłości, jest metafora pyłu oraz światła. Kurz osadzający się na budynkach, pomnikach, skwerach pomaga nawiązywać do upływu czasu i do historii. „Zidovi [su] sivi od pamćenja"18 [s. 30] — czytamy. W świecie przedstawionym spotykamy się także z metaforą świetlistego prochu — ,svetlosne prašine koja jedna pamti sve što se zbivalo i što se zbiva" [s. 18]. Jeszcze innym środkiem pozwalającym snuć narracje o przeszłości jest wprowadzenie metaforyki światła. Otwiera ona drogę do innych wymiarów czasowych, służy jako retardacja. W okolicznościach iluminacji pojawiają się i odchodzą ze świata przedstawionego związane z miastem postaci historyczne. Kolejnymi atrybutami fragmentów dotyczących przeszłości są miejski bezruch i milczenie. O ile stare, zakurzone obiekty są nośnikami pamięci, dotarcie do depozytu następuje tylko w warunkach spokoju — głosy przeszłości wybrzmiewają wtedy, gdy obserwator ma dostęp do ,archaicznej ciszy”.

\section{Pamięć w przestrzeni - miejsca}

W zbiorze opowiadań Velmar-Janković szczególnego znaczenia nabiera kategoria miejsca, ,przestrzeń urealniona zmysłowo i rozumowo"19, opracowana intelektualnie i emocjonalnie, wyróżniona przez podmiot. Topografia Belgradu przechodzi złożony mentalny proces mappingu, w którym kartograficzne punkty odniesienia stają się ,punktami przecięcia między przestrzenią i czasem, stworzonymi w toku przewarstwienia struktur fizyczno-przestrzennych przez (subiektywne) akty pamięci" ${ }^{20}$. Na mapie Dorciolu autorka zaznacza bardzo wiele punktów mających

17 M. Mendel, W. Theiss, Od redaktorów, [w:] Pamięć i miejsce. Perspektywa spoleczno-edukacyjna, red. M. Mendel, W. Theiss, Gdańsk 2019, s. 16.

18 Wszystkie cytaty z tekstu źródłowego na podstawie wydania: S. Velmar-Janković, Dorćol, Beograd 2014. Numery stron są umieszczone w nawiasach kwadratowych.

19 P. Zwierzchowski, Przestrzeń i miejsce jako kategoria wyjaśniajaca relacje: dziecko-rodzina-szkoła, 1995, https://repozytorium.ukw.edu.pl/bitstream/handle/item/1461/Piotr\%20Zwierzchowski $\% 20 \% 20$ Przestrzen $\% 20 \mathrm{i} \% 20$ miejsce $\% 20$ jako $\% 20$ kategorie $\% 20$ wyjasniajace $\% 20$ relacje\%20dziecko\%20rodzina\%20szkola.pdf?sequence=1\&isAllowed=y [dostęp: 15.04.2019].

20 D. Bachmann-Medick, Cultural turns..., s. 359. 
własną opowieść: niektóre z nich są w relacji do ważnych postaci albo wydarzeń, stając się „miejscami pamięci”, ekwiwalentami „nieistniejącej już, naturalnej pamięci zbiorowej" 21 , inne to fragmenty miasta, których dzisiejsze zagospodarowanie nie wskazuje na związki z przeszłością.

W opowiadaniu Francuska ulica Velmar-Janković odkrywa historyczność obszaru, który był niegdyś granicą Starego Belgradu, oznaczaną i szczególnie zagospodarowywaną przez kolejnych włodarzy miasta. Od Kalemegdanu po Dorciol wznosił się szaniec, niszczony i odbudowywany wraz z biegiem dziejów, widoczny jeszcze na planach Emiliana Josimovicia z 1867 roku. Najmocniejsze piętno na nim odcisnęli Austriacy, którzy wybudowali szeroki mur obronny wraz z bramami, dodatkowo opasany głębokim wykopem. Za czasów tureckich zniszczoną przez wycofującą się armię austriacką fortyfikację zmieniono wysoką palisadą, którą ulokowano na tym samym miejscu. Historia budowli, jak pisze autorka, dobiega końca dopiero w latach sześćdziesiątych i siedemdziesiątych XIX wieku, kiedy Serbowie przystępują do jej zupełnego wyburzenia.

Najważniejszy punkt dawnych granic miasta znajdował się w okolicach bramy zwanej Stambulska kapija, na współczesnym placu Republiki. Pisarka zwraca uwagę na trwałość ustnego przekazu dotyczącego tego miejsca, podkreślając, że wśród narracji funkcjonujących w pamięci zbiorowej zachowały się przede wszystkim te niezwiązane $\mathrm{z}$ wielkimi historycznymi wydarzeniami, ale z wyjątkowymi, nieco nadrealnymi doświadczeniami mieszkańców, które można interpretować jako strach przed własną przeszłością.

Jedno z podań miejskiego folkloru dotyczy wspomnianej bramy, która miała dla mieszkańców wyjątkowo złowrogą symbolikę, związaną z tureckim zwyczajem wystawiania na widok publiczny głów lokalnych buntowników. Do powracających we wspomnieniach należą też dzieje dziesiątkującej miasto epidemii, a przenikającej do jego szczelnie ogrodzonego wnętrza, jak sądzono, właśnie przez główną bramę. Pamięć o jej niezwykłości zachowała się do drugiej połowy XIX wieku, przybierając formę przesądów, które dały o sobie znać w chwili usuwania resztek palisady.

Pamięć o historii okolic ulicy Francuskiej nie była udziałem majętnych i dostojnych obywateli. Od lat siedemdziesiątych XIX stulecia w procesie przeobrażania miasta wedle potrzeb jego nowych, serbskich, mieszkańców czynnik sentymentalny nie odgrywał żadnej roli. Wiedza o dawniejszych strukturach miasta była wypierana ze świadomości, więc wzdłuż dawnego szańca wznoszono okazałe domostwa. Podjęta przez serbskie władze modernizacja oznaczała zrywanie z przeszłością, racjonalne odcinanie się od obcych, ale i własnych tradycji. Nie kontynuowano dotychczasowych funkcji określonych fragmentów przestrzeni, co spowodowało, że z miejskiego pejzażu usunięto tureckie ogrody i serbskie winnice. Belgrad odbudowywano zgodnie z wzorem zaczerpniętym z zachodnich me-

21 A. Erll, Kultura pamięci: wprowadzenie, przeł. A. Teperek, posł. i red. M. Saryusz-Wolska, Warszawa 2018. 
tropolii, wyznaczając szerokie ulice, wznosząc wysokie kamienice, wytyczając otwarte place. Fakty te wskazują na istotność zasobu, jakim jest przestrzeń, a także na jej społeczne wytwarzanie, które „nie polega na tym, że wszyscy zainteresowani milcząco i intuicyjnie zgadzają się co do tego, w jakiej przestrzeni żyją, lecz na tym, że zainteresowani komunikują się, negocjują i walczą ze sobą"22.

Przykładem nostalgicznie traktowanego przez Velmar-Janković ważnego budynku, który zniknął bez śladu, jest konak ${ }^{23}$ dahii Kučuk Aliji, dowódcy belgradzkich janczarów. Uczestniczył on w 1804 roku w wydarzeniu zwanym seča knezova, podczas którego stracono serbskich dostojników. W trakcie powstania, po zdobyciu Belgradu, w konaku zamieszkał Mladen Milovanović, najbogatszy człowiek w Serbii, doradca Karađorđa, potem naczelnik Belgradu, a wreszcie premier powstańczego rządu. Historia tego budynku ma swój ciąg dalszy i wiąże się z rezydowaniem w nim rosyjskiego konsula Rodofinkina. Velmar-Janković przywołuje pamięć o tym nieistniejącym już miejscu, pokazując, że wraz z wykreśleniem obiektu $\mathrm{z}$ mapy miasta unicestwione zostają historie związanych z nim ludzi.

$\mathrm{Na}$ etapie dynamicznego rozwoju Belgradu społeczeństwo nie wykazywało skłonności do pamięci historycznej. Jak twierdzi Velmar-Janković, przypadłością ogółu jest raczej zapominanie i koncentracja na tym, co teraźniejsze. „Takve su pojedinosti, kao i obično, prosto iščezavale u darmaru prolaznosti” [s. 16] — pisze. Jakby na przekór temu w świecie przedstawionym Dorćolu przestrzeń dawnej granicy jest wielopiętrową konstrukcją historyczną, zachęcającą do odczytywania miasta. Podejmowana przez nią próba rekonstrukcji przeszłości ulicy Francuskiej nadaje jej charakter miejsca, wskazuje na rozmaite, zmieniające się w czasie znaczenia.

Postaci zaludniające świat przedstawiony utworu Velmar-Janković zauważają rozmaite ingerencje w miejski krajobraz, zastanawiając się nad ich słusznością. Jevrem Obrenović, brat księcia Miloša, współczesną architekturę Dorciolu nazywa brzydką. Na jej tle wyróżniają się dwa budynki — dom Božicia oraz Muzeum Vuka i Dositeja. Jest przy nich najwięcej światła i wolnej przestrzeni, nie przytłaczają wysokością, napawają spokojem. Podwórze starego konaku to miejsce, w którym zatrzymał się czas, w którym każde przedpołudnie wygląda od lat identycznie. Konak, nawiasem mówiąc, jest we wszystkich opowiadaniach traktowany jako synonim przyjaznej użytkownikom, wygodnej architektury. W opowiadaniu Ulica Gospodar Jevremova napotykamy nawet wątpliwości, czy okazałe Kapetan Mišino zdanje musiało stanąć na parceli, na której znajdował się dwór Jevrema, nowo wybudowany konak w zeuropeizowanym stylu.

Bohaterowie utworu z nostalgią odnoszą się do tradycji kupieckich swej dzielnicy. Dostrzegają, że brakuje rzemieślniczych zakładów i zanika handel uliczny, istniejący tu przez stulecia, a nawet będący wizytówką całego Belgradu.

22 M. Löw, Socjologia przestrzeni..., s. 17.

23 Więcej na temat tego typu domów mieszkalnych zob. M. Chaszczewicz-Rydel, Pierwiastki osmańskie w architekturze miast południowej Serbii, „Południowosłowiańskie Zeszyty Naukowe. Język, Literatura, Kultura. Bałkany” 2010, nr 7, s. 253-264. 


\section{Pamięć ludzi miasta}

Velmar-Janković, wskazując patronów ulic Dorciolu, buduje panoramę serbskiego mieszczaństwa. Czyni to na ogół wedle podobnej zasady. Postaci z przeszłości, zawieszone w historycznym międzyczasie, chadzają ulicami własnego imienia oraz $\mathrm{w}$ ich sąsiedztwie. W teraźniejszości dostrzega je jedynie zakorzeniony głęboko w dorciolskiej rzeczywistości narrator, który swobodnie przechodzi między planami czasowymi.

Wśród pojawiających się w opowiadaniach osobowości najwyraźniej zarysowują się dwie - Jevrem Obrenović i Dositej Obradović. Historia o Jevremie Obrenoviciu, młodszym bracie księcia Miloša, poświęcona jest konsekwencjom decyzji politycznych bohatera, który był mianowany komendantem miasta Belgradu. Przytoczone fragmenty jego biografii dają wgląd w życie społeczno-polityczne Serbii lat trzydziestych. Dowiadujemy się z nich wiele o okolicznościach sporu wokół ograniczenia prerogatyw władcy i wprowadzenia konstytucji z 1838 roku, o działaniu nieformalnej dyplomacji, o dworskich intrygach, ale i balach.

Z kolei cztery lata przebywania Dositeja Obradovicia w Belgradzie (umarł w roku 1811) Velmar-Janković ujmuje w schemat jego ostatniej podróży — fizycznej, gdyż pięciokrotnie zmieniał miejsce zamieszkania, i intelektualnej, bo związanej z licznymi przedsięwzięciami. Miejsca pobytu określają tryb życia i stan ducha bohatera. Każde z nich było znakiem „kojim se obeležavalo jedno novo njegovo iskustvo o razlozima postojanja" [s. 180]. Obradović początkowo zamieszkuje w honorowej lokalizacji, w starym dworze paszów na Górnym Mieście na Kalemegdanie, dokąd został odprowadzony w sierpniu 1807 roku przez thum mieszkańców oswobodzonego miasta. Obiekt ten był symbolem tureckiej siły, ale właśnie tu Dositej doświadcza niemocy i odczuwa zmęczenie. Ze względu na chorobę zostaje przeniesiony do otoczonego winnicą domu kapitana Petara Novakovicia Čardakliji. Panuje tu spokój, płynący z uporządkowanego życia mieszkańców. W sprzyjającej rekonwalescencji atmosferze serbski oświeceniowiec oddaje się lekturze ulubionej literatury i udziela lekcji synowi Karađorđa - Aleksowi. Po śmierci Čardakliji, w lutym 1808 roku, Dositej nie chce dłużej przebywać w jego opustoszałym domu. Przyjmuje zaproszenie od rosyjskiego konsula Rodofinkina i przenosi się do konaku Kučuk Alii. Pobyt w domu otwartym na gości, w którym wrzało od towarzyskich i politycznych intryg, zmusza bohatera do ostrożności i wzmaga zmęczenie. Czeka końca prac nad budynkiem, który kupił wraz z przybyciem do Belgradu, by wreszcie znaleźć wytchnienie we wzniesionym u zbiegu dzisiejszych ulic Dositeja i Braci Jugoviciów konaku z wykuszem. Znalazł tu warunki do pracy, a jednocześnie pielęgnował ogród i własną winnicę. W tym czasie doglądał też spraw związanych z założeniem drukarni, a 1 września 1808 roku swą mową uświetnił otwarcie Wielkiej Szkoły. W dwa lata później zaczęła działać założona w jego domu szkoła klerykalna Bogoslavija. Powołany przez Karađorđa na misję do Bukaresztu, wraca z niej w 1811 roku, natychmiast otrzymując tekę ministra 
oświaty, po czym wprowadza się do siedziby rządu, skąd, obłożnie chory, obserwował turecki cmentarz.

Dokonania Dositeja zapisały się w historii i państwa i miasta, które odpłacają mu się uwiecznieniem jego brązowej podobizny w parku Studenckim, okolicy jego ostatniego schronienia.

\section{„Nie-miejsca pamięci”}

Roma Sendyka ${ }^{24}$, nawiązując do koncepcji miejsc pamięci, miejsc tragicznych wydarzeń, a także elementów przestrzeni związanych z eksterminacją, wprowadza kategorię ,nie-miejsca pamięci”, nazywając w ten sposób nieoznaczone punkty topograficzne, które mogły stać się miejscami pamięci. Za takie nie-miejsce można uznać skrzyżowanie, od którego Dorciol przyjął nazwę. Velmar-Janković przytacza opowieść Filipa Hristicia, ministra i dyplomaty, według którego stary Dort-jol był przestrzenią wykonywania kary śmierci. Do zdarzeń tych dochodziło pod koniec XVIII wieku i w początkach wieku XIX. W samo południe doprowadzano osądzonego do skrzyżowania, a po wykonaniu wyroku ciało straconego jako przestrogę pozostawiano na widok publiczny jeszcze na dwa dni. Miejsce kaźni było oznaczone kamiennym głazem, tak zwanym kamieniem śmierci. Dziś nie ma śladu po mrocznym rytuale, na skrzyżowaniu odbywa się codzienny uliczny ruch. Autorka stara się jednak przekonać czytelników, że nad ulicami unosi się nawiązujący do tragicznej przeszłości krąg czarnego światła: „Teško se, u celini, raspoznaje zbog automibila koji ga uzalud gaze dok crna svetlost, sa godinama sve neproznija, počinje da klizi uz padinu i da, polako, uznemirava prahove prošlosti” [s. 218].

$* * *$

Zbiór opowiadań Svetlany Velmar-Janković pod tytułem Dorćol poddaje się analizie pod kątem pamięci miejsca. Autorka łączy narrację o historii z fikcją literacką, porusza się między planami czasowymi, korzystając z koncepcji czasu cyklicznego, wprowadza elementy cudowności, idealizuje przeszłość, co przesuwa jej tekst ku kulturze popularnej ${ }^{25}$. Belgrad przedstawia jako dynamiczne miasto, a jego topografia służy jej do odczytywania miejskich opowieści, zapisanych $\mathrm{w}$ wybranych przez nią punktach topograficznych, którym nadaje rangę miejsc.

Jako pisarka urodzona i wychowana na Dorciolu podkreśla, że wiedza o zdarzeniach, które opisuje, dostępna jest w pełni jedynie najstarszym mieszkańcom dzielnicy. Choć nazwy ulic mówią o postaciach historycznych, dla ogółu społe-

24 R. Sendyka, Pryzma - zrozumieć nie-miejsca pamięci (non-lieux de memoire), „Teksty Drugie" 2013, nr 1-2, s. 323-344.

25 Por. Popkulturowe formy pamięci, red. S. Buryła, L. Gąsowska, D. Ossowska, Warszawa 2018. 
czeństwa są one nierozpoznawalne. Takiemu stanowi rzeczy sprzyja fakt, że okres pierwszej połowy XIX wieku nie jest dostatecznie reprezentowany w architekturze oraz pejzażu Belgradu. Tym samym liczba tutejszych zabytków nie odpowiada długowiecznej historii bałkańskiej metropolii, która ma dziś inne główne arterie, a Dorciol ustępuje miejsca innym kwartałom miasta, przeznaczonym na wizytówki stolicy i Serbii.

Z całą pewnością wirtualnym odbiorcą książki Velmar-Janković nie są przyjezdni, kieruje ona swój utwór do czytelników rodzimych: do Serbów, belgradczyków i tych, którzy do miana belgradczyka aspirują. Bohaterowie i miejsca będące częścią opowieści o Dorciolu są składnikami mitu rodzącej się Serbii, a jednocześnie dość antynowoczesnej koncepcji historycznej. Można w niej dostrzec znamiona Baumanowskiej retrotopii, „mechanizmu obronnego opartego na obietnicy odbudowy ojczyzny idealnej”26. Można też zbiór Velmar-Janković sytuować w kontekście ponownego odkrycia lokalności albo „konstruktywnego odwołania ku sile społeczności, wynikającej z jej historyczno-kulturowego dziedzictwa"27. W każdym wypadku jest warte zaakcentowania, że pamięć zapisana w przestrzeni publicznej zawsze pozostaje $\mathrm{w}$ związku z procesem samookreślania, który zachodzi w sposób ciągły między innymi dzięki „miejscom dla ludzi ważnym, budzącym emocje" 28 .

\section{Bibliografia}

Bachmann-Medick D., Cultural turns. Nowe kierunki w naukach o kulturze, przeł. K. Krzemieniowa, Oficyna Naukowa, Warszawa 2012.

Bauman Z., Retrotopia, jak rządzi nami przeszłość, przeł. K. Lebek, Wydawnictwo Naukowe PWN, Warszawa 2018.

Bura N., Ilustrovana hronologija Beograda, Prometej, Novi Sad 2004.

Chaszczewicz-Rydel M., Pierwiastki osmańskie w architekturze miast południowej Serbii, „Południowosłowiańskie Zeszyty Naukowe. Język, Literatura, Kultura. Bałkany” 2010, nr 7.

Erll A., Kultura pamięci: wprowadzenie, przeł. A. Teperek, posł. i red. M. Saryusz-Wolska, Wydawnictwa Uniwersytetu Warszawskiego: Niemiecki Instytut Historyczny, Warszawa 2018.

Istorijski atlas Beograda, oprac. D. Lakićević, Bookland, Beograd 2016.

Jałowiecki B., Społeczne wytwarzanie przestrzeni, Wydawnictwo Naukowe Scholar, Warszawa 2010.

Korzeniowski B., Transformacja pamięci: przewartościowania w pamięci przeszłości a wybrane aspekty funkcjonowania dyskursu publicznego w Polsce po 1989 roku, Wydawnictwo Poznańskiego Towarzystwa Przyjaciół Nauk, Poznań 2010.

Löw M., Socjologia przestrzeni, przeł. I. Drozdowska-Broering, red. i wprowadz. M. Bucholc, Wydawnictwa Uniwersytetu Warszawskiego, Warszawa 2018.

Mnemosyne. Pamięć jako źródło dzieła sztuki, red. M. Cieśla-Korytkowska, J. Czernik, seria „Komparatystyka Polska — Tradycja i Współczesność”, Wydawnictwo Avalon, Kraków 2016.

Pamięć i miejsce. Perspektywa spoteczno-edukacyjna, red. M. Mendel, W. Theiss, Wydawnictwo Uniwersytetu Gdańskiego, Gdańsk 2019.

26 Z. Bauman, Retrotopia, jak rzadzi nami przeszłość, przeł. K. Lebek, Warszawa 2018, s. 10.

27 M. Mendel, W. Theiss, Od redaktorów..., s. 13.

28 B. Jałowiecki, Społeczne wytwarzanie przestrzeni, Warszawa 2010, s. 17.

Slavica Wratislaviensia 173, 2020

(C) for this edition by CNS 
Popkulturowe formy pamięci, red. S. Buryła, L. Gąsowska, D. Ossowska, Instytut Badań Literackich PAN, Warszawa 2018.

Przestrzeń spoleczna miast i metropolii w badaniach socjologicznych, red. Z. Rykiel, Wydawnictwo Uniwersytety Rzeszowskiego, Rzeszów 2014.

Rogowska M., Przestrzeń publiczna w mieście. Zagadnienia wybrane, „Studia KPZK” 2016, nr 170. Saryusz-Wolska M., Pamięć zbiorowa i kulturowa. Wspótczesna perspektywa niemiecka, red.

M. Saryusz-Wolska, Universitas, Kraków 2009.

Sendyka R., Pryzma — zrozumieć nie-miejsca pamięci (non-lieux de memoire), „Teksty Drugie” 2013, nr 1-2.

Velmar-Janković S., Dorćol, Laguna, Beograd 2014.

Woźniak R., Miejsce do mieszkania, miejsce do kochania..., Wystawa Katedry Sztuki i Kultury Plastycznej Uniwersytetu Zielonogórskiego, przeł. A. Rozwadowska, W. Prankiewicz, Galeria BWA Zielona Góra, Zielona Góra 2007.

Zamurović D., Moj Beograd, Laguna, Beograd 2013.

Zwierzchowski P., Przestrzeń i miejsce jako kategoria wyjaśniajaca relacje: dziecko-rodzina-szkota, 1995 , https://repozytorium.ukw.edu.pl/bitstream/handle/item/1461/Piotr\%20Zwierzchowski $\% 20 \% 20$ Przestrzen $\% 20 \mathrm{i} \% 20$ miejsce $\% 20$ jako $\% 20$ kategorie $\% 20$ wyjasniajace $\% 20$ relacje $\% 20$ dziecko\%20rodzina\%20szkola.pdf?sequence=1\&isAllowed=y.

\section{The Public Space of Belgrade and Its Literary Transformations - Svetlana Velmar-Janković}

Summary

The topic of this article is a short story collection by Svetlana Velmar-Janković, entitled Dorćol. It is analyzed for the relationship between memory and place. By this example I try to show how the public space issue and the question of identity related to it are reflected in Serbian literature.

Keywords: memory of place, public space, identity, Belgrade, Svetlana Velmar-Janković

\section{Памћење у друштвеном простору Београда и његове књижевне трансформације}

Резиме

У овом чланку бавим се збирком приповедака Дорћол Светлане Велмар-Јанковић. Критеријум анализе је веза памћења и места. На овом примеру желим да покажем како се у књижевности одбија питање друштвеног простора и уз њега везан проблем идентитета.

Кључне речи: мапирање сећања, друштвени простор, идентитет, Београд, Светлана Велмар-Јанковић

Slavica Wratislaviensia 173, 2020

(C) for this edition by CNS 